ФОРМУВАННЯ ДУХОВНИХ ЦІННОСТЕЙ І ДУХОВНОЇ КУЛЬТУРИ В УНІВЕРСИТЕТАХ КИТАЮ: ТЕОРЕТИЧНІ АСПЕКТИ

\title{
FORMATION OF SPIRITUAL VALUES AND SPIRITUAL CULTURE AT CHINA UNIVERSITIES: THEORETICAL ASPECTS
}

УДк 2.1

DOI https://doi.org/10.32843/26636085/2020/24-1.40

\section{Лю Мейхуанъ,}

аспірант кафедри педагогіки, іноземної фрілології та перекладу

Харківського національного економічного університету імені Семена Кузнеця, доцент кафедри музики та виконавства Університету мистецтв і науки Сичуань, Китай

Кравченко Г.Ю., докт. пед. наук, доцент кафедри педагогіки, іноземної фрілології та перекладу Харківського національного економічного університету імені Семена Кузнеця

\begin{abstract}
Статтю присвячено актуальній проблемі формування духовних цінностей $і$ духовної культури у майбутніх вчителів музики. Розглянуто особливості розуміння гуманістичної спрямованості підготовки педагогів музики, здійснено актуалізацію уваги на теоретичний і методичний аспекти досвіду університетів Китаю.
\end{abstract}

У змісті проаналізовано поняття «духовна культура суспільства Китаю», яке включає в себе відтворення індивідуальної і суспільної свідомості; народну художню культуру; мистецтво як професійний вид художньої творчості; естетичну культуру; культуру наукового життя; культуру утворення; культуру виховання; культуру волі совісті; культуру морально-духовного життя; інфрормаційну культуру. Зазначено, що в Китаї термін «духовна культура» здебільшого включає в себе художню освіту, естетичне виховання та гуманістичне вдосконалення. На основі аналізу науковометодичних джерел визначено цілі естетичної освіти та їх значення у всебічному розвитку освіти Китаю.

Розкриваючи поняття «естетичного виховання» авторами досліджено розуміння взаємозв'язку понять «духовна культура», «естетичне виховання» та «художня освіта» з позиції та поглядів науковців різних країн. Виходячи з чих позицій, з'ясовано, що духовна культура в коледжах та університетах Китаю стосується розуміння естетичної освіти, яка визначає природну красу, соціальну красу та мистецьку красу для формування та розвитку духовності студентів закладів вищої освіти, вдосконалення ї здатності відчувати, цінувати і творити красу, а також культивувати ії правильні естетичні концепції, естетичні ідеали. Навчальні ресурси, методи викладання в коледжах та університетах Китаю забезпечують студентам більше свободи у навчанні, впливають на розвиток духовного та культурного мислення студентів більше, ніжу закладах середньої освіти. Тому художні дисципліни викладачів здебільшого включають музику, мистецтво, танець та інші спеціальності. Естетична освіта керується естетичними теоріями, основними каналами яких є мистецтвознавство. Ключові слова: культура, духовнакультура, духовні чінності, естетичне виховання, цілі естетичної освіти, художня освіта, гуманістичне вдосконалення, університет.

The article is devoted to the urgent problem of the formation of spiritual values and culture of future music teachers. Peculiarities of understanding the humanistic orientation of the training of music teachers are considered, attention is paid to the theoretical and methodological aspects of understanding this issue at universities in China. The content of the article analyzes the concepts of the spiritual culture of Chinese society, which includes the reproduction of individual and social consciousness; folk art culture; art as a professional form of art; aesthetic culture; culture of scientific life; educational culture; culture of education; culture of the will of conscience; culture of moral and spiritual life; information culture. It is noted that in China, the concept of "spiritual culture" includes art education, aesthetic education and humanistic improvement. Based on the analysis of scientific and methodological sources, the goals of aesthetic education and their importance in the comprehensive development of China's education are determined. Revealing the concept of aesthetic education, the author explores the understanding of the relationship between the concepts of "spiritual culture", "aesthetic education" and "art education" from the position and views of scientists from different countries.

Based on these positions, it was found that the spiritual culture in colleges and universities of China concerns the understanding of aesthetic education, which defines natural beauty, social beauty and artistic beauty for the formation and development of spirituality of students of higher education institutions, improving their ability to feel, appreciate and create beauty, and also cultivate its correct aesthetic concepts, aesthetic ideals.

Learning resources, teaching methods in colleges and universities in China provide students with more freedom in learning, affect the development of spiritual and cultural thinking of students than in secondary education institutions. Therefore, the artistic disciplines of teachers mainly include music, art, dance and other specialties. Aesthetic education is guided by aesthetic theories, the main channels of which are art history. Key words: culture, spiritual culture, spiritual values, aesthetic education, goals of aesthetic education, art education, humanistic improvement, university.
Постановка проблеми в загальному вигляді. Вивчення й аналіз педагогічних надбань теоретиків і практиків освіти уможливлюють розуміння гуманістичної основи духовної культури в контексті формування ціннісного ставлення майбутніх педагогів музики до мистецтва, їх здатності до адекватної оцінки здобутків мистецтва; до педагогічної, викладацької та науково-дослідницької діяльності.

Формування духовних цінностей та духовної культури студентства здійснюється зі значними труднощами, викликаними певними причинами. По-перше, в освіті з'явилися прагматичні компоненти, які помітно впливають на ії зміст, «вимиваючи» фрундаментальну освіту, тобто здійснюється підготовка вузького спеціаліста, який ефективно виконує призначені йому функції. По-друге, багато студентів позбавлені належного родинного плекання через психолого-педагогічну непідготовленість батьків до естетичного виховання. Саме тому у юнацькому віці молода людина не має не 
тільки позитивного духовно-морального досвіду, а й доброї основи для формування духовних цінностей і духовної культури.

Аналіз останніх досліджень і публікацій. Відтворення генерації цілісності духовної культури аналізується крізь призму взаємовпливу особистості та творчості в умовах держави вченими В. Липинським, Г. Моски, У. Парето, О. Тоффрлером та іншими. Теоретико-методологічні засади духовної культури відображені й у роботах В. Андрущенка, Є. Бистрицького, І. Бойченка, М. Бровка, Л. Губерського, І. Зазюна, В. Іванова, Л. Левчук, М. Лукашевича, М. Мокляка, І. Надольного, В. Шинкарука та інших.

Вивчення й аналіз педагогічних надбань теоретиків і практиків освіти уможливлює розуміння гуманістичної спрямованості підготовки музичних педагогів як актуалізації теоретичного й методичного досвіду в контексті особистісно спрямованого навчання, що забезпечується реалізацією оцінного ставлення вихованців до музичних явищ із позицій духовних цінностей.

Дослідження формування духовних цінностей і духовної культури висвітлюються в концепціях науковців і практиків І. Беха, В. Дряпіки; провідні аспекти педагогічного профресіоналізму розглянуто крізь фрормування його ціннісних основ у наукових працях $Є$. Бондаревської, В. Сластьоніна, $€$. Шиянова.

Результати наукових пошуків з питань музикознавства, психології художньої творчості Б. Асафьєва, О. Костюка, В. Медушевського, Є. Назайкінського покладено в основу обґрунтування концепції впливу різних видів і жанрів музичного мистецтва на формування ціннісних орієнтацій особистості в художній сфрері.

Дослідження змісту й основних компонентів ціннісних орієнтацій юнацтва в художній сорері О. Олексюка, Г. Падалки, Р. Шульги сприяють забезпеченню необхідної спрямованості навчального процесу в галузі музично-педагогічної освіти. Дивлячись на сучасний стан мистецької освіти у світі, більшість із них зосереджується на художній освіті студентів, менше досліджень стосуються формування духовної культури студентів-бакалаврів музично-педагогічного профрілю - майбутніх вчителів музики.

Дослідженням художньої грамотності майбутніх викладачів або викладачів коледжів у Китаї приділяв увагу науковець Лін Євей (2014). Він опублікував статтю «Деякі думки щодо вдосконалення художньої грамотності вчителів». Автор розкрив особливості профресії вчителів і заявив, що наявність художньої грамотності вчителя відіграє дуже важливу роль у навчанні та вихованні [5] Ян Сяо (2011) у «Розмові про художню грамотність вчителів коледжу, які вдосконалюють художню грамотність вчителів, починаючи з культурної гра- мотності» вважає, що походження мистецтва так само давнє, як і походження людської культури, і це етап історичного розвитку людської культури та культурний вияв цивілізації [15].

Отже, фрормування художньої грамотності викладачів у коледжах та університетах повинно починатися із вдосконалення різної культурної грамотності. Сорормований вищий культурний рівень викладачів у коледжах та університетах дає змогу правильно пояснити та зрозуміти характеристики мистецьких часів, що сприяє правильній інтерпретації мистецтва та його надбань, теоретичному узагальненню та сублімації дизайнерських ідей та дизайнерських концепцій.

Крім того, інші вчені висунули свої погляди щодо важливості художньої грамотності. Лі Ланкін (2004) вважає, що мистецтво, представлене музикою, може покращити роботу та ефективність людей, може дати натхнення та натхнення керівництву; Чен Ронгуа (2007) в «Унікальній ролі талантів» також вказувала на те, що мистецтво може відкрити людям розуміння, сприйняття, спостережливість, мислення, творчість та уяву [14].

Завдяки мистецькій практиці, такій як художня творчість та оцінювання мистецтва, доведено, що воно може формувати здорову особистість та пропагувати фрізичне й психічне здоров'я людей. Так, профресор Чжоу Іньчан у своїй лекції на тему «Культурно-мистецьке культивування та якість людей» зазначив: «Спершу ми повинні знати, що таке музика, а потім обирати їі відповідно до наших правильних науковихічудових естетичнихконцепційта стандартів. Заходьте, подивіться на нашу культуру, дайте людям здорову, найкращу духовну їжу» [12].

Мета статті. Метою статті $€$ теоретичне обґрунтування основ фрормування духовних цінностей і духовної культури студентської молоді в закладах вищої освіти Китаю.

Виклад основного матеріалу. Термін «культура» (від лат. cultura - оброблення, виховання, освіта, розвиток, шанування) - специфрічний спосіб організації і розвитку людської життєдіяльності, уявлень у продуктах матеріальної і духовної праці, в системі соціальних норм і закладів, в духовних цінностях, у сукупності ставлення людей до природи, між собою і до самих себе. Культура характеризує також особливості свідомості, поведінки й діяльності людей у конкретних сорерах суспільного життя. «Культура праці», «екологічна культура», «політична культура» - так тлумачить це поняття Філософський енциклопедичний словник [6].

Німецькі фрілософи пошуки культури продовжили у сорері «духу», в сорері моральної (Кант), естетичної (Шиллер, романтизм) або фрілософської (Гегель) свідомості, яка постає як галузь духовної свободи людини. Марксистська концепція культури заснована на принципах історичного матеріалізму. Культура $€$ специфрічною характе- 
ристикою суспільства і виражає досягнутий людством рівень історичного розвитку, що включає в себе певне ставлення людини до природи і суспільства, а також розвиток творчих сил і здібностей особистості.

Культура включає в себе не тільки предметні результати діяльності людей (машини, технічні споруди, результати пізнання, твори мистецтва, норми права й моралі), а й суб'єктивні людські сили і здібності, які реалізуються в діяльності (світогляд, знання й уміння, виробничі й профресійні навички, рівень інтелектуального, естетичного і морального розвитку, способи і фрорми взаємного спілкування людей у колективі і суспільстві) [4].

Духо́вна культу́ра - частина культури, до складу якої входять мистецтво, релігія, фрілософрія. Духовна культура постає як система сфер, що взаємодіють між собою і складають єдине ціле [11]. Філософрія специфрічним чином торкається проблем краси, істини і добра. Філософрія $€$ всебічною і загальною фрормою культури, квінтесенцією духовної культури.

Поняття «духовна культура» включає всі галузі духовної сфери; показує соціально-політичні процеси, які відбуваються у суспільстві. Духовна культура - багатошарове утворення, що включає в себе пізнавальну, моральну, художню, правову й інші культури; це сукупність нематеріальних елементів: норми, правила, закони, духовні цін- ності, церемонії, ритуали, символи, міфри, мова, знання, звичаї. Будь-який об'єкт нематеріальної культури має потребу в матеріальному посереднику, наприклад книга [2].

Духовна культура - сорера людської діяльності, яка охоплює різні сторони духовного життя людини і суспільства. Духовна культура містить у собі форми суспільної свідомості і їхнє втілення в літературні, архітектурні й інші пам'ятники людської діяльності. Виступаючи якісним показником духовного життя суспільства, духовна культура по своїй структурі духовної сорери громадського життя складає єдність таких компонентів, як духовна діяльність, духовні потреби, духовне споживання, соціальні інститути, духовні відносини і спілкування [3].

Духовна культура суспільства включає відтворення індивідуальної і суспільної свідомості; народну художню культуру; мистецтво як профресійний вид художньої творчості; естетичну культуру; культуру наукового життя; культуру утворення; культуру виховання; культуру волі совісті; культуру морально-духовного життя; інорормаційну культуру.

Проаналізувавши різні визначення терміну «духовна культура» можна зазначити, що духовна культура як поняття визначається науковцями за різними ознаками: як сорера духовної діяльності, яка включає систему освіти, виховання, духовної творчості (заняття наукою, політикою, етикою, мистецтвом, фрілософрією, релігією, правом); як

\section{Цілі естетичної освіти у всебічному розвитку освіти Китаю}

\begin{tabular}{|c|c|c|}
\hline Рік & Політика КНР & Цілі всебічного розвитку освіти \\
\hline 1906 & Про мету навчання (Ван Говей) & $\begin{array}{l}\text { Фізичне виховання, розумове виховання (розумне вихо- } \\
\text { вання, моральне виховання, естетичне виховання) }\end{array}$ \\
\hline 1912 & Центральна асоціація тимчасової освіти & $\begin{array}{l}\text { Військово-патріотичне виховання громадян, утиліта- } \\
\text { ризм, громадянська мораль, світогляд, естетична освіта }\end{array}$ \\
\hline 1915 & $\begin{array}{l}\text { Контур освіти (під час реставрації імператора } \\
\text { Юаня Шикая) }\end{array}$ & Мораль, прибуток і бойові мистецтва \\
\hline 1931 & $\begin{array}{l}\text { Принципи трьох народних принципів освіти } \\
\text { (Національний уряд) }\end{array}$ & $\begin{array}{l}\text { Моральне виховання, інтелектуальне виховання, есте- } \\
\text { тичне виховання (спорт) }\end{array}$ \\
\hline 1951 & $\begin{array}{l}\text { Перша національна конференція про середню } \\
\text { освіту (скликана Міністерством освіти) }\end{array}$ & $\begin{array}{l}\text { Інтелектуальне, моральне, фрізичне виховання, есте- } \\
\text { тичне виховання }\end{array}$ \\
\hline 1957 & Про належне вирішення протиріч між людьми & $\begin{array}{l}\text { Моральне виховання, естетичне виховання, фрізичне } \\
\text { виховання }\end{array}$ \\
\hline 1986 & $\begin{array}{l}\text { Звіт сьомої п'ятирічки Національного народ- } \\
\text { ного конгресу }\end{array}$ & $\begin{array}{l}\text { Моральне виховання, інтелектуальне виховання, } \\
\text { фрізичне виховання, естетичне виховання, трудове } \\
\text { навчання }\end{array}$ \\
\hline 1990 & $\begin{array}{l}\text { Звіт про роботу уряду на III сесії Сьомого наці- } \\
\text { онального народного конгресу }\end{array}$ & $\begin{array}{l}\text { Моральна освіта, інтелектуальна освіта, фрізичне вихо- } \\
\text { вання }\end{array}$ \\
\hline 1999 & $\begin{array}{l}\text { Національний конгрес з питань освіти } \\
\text { «Рішення ЦК КПК та Державної ради про } \\
\text { поглиблення редорми освіти та всебічне під- } \\
\text { вищення якості освіти» }\end{array}$ & $\begin{array}{l}\text { Моральне виховання, інтелектуальне виховання, } \\
\text { фрізичне виховання, естетичне виховання }\end{array}$ \\
\hline 2013 & $\begin{array}{l}\text { Третя пленарна сесія 18-го Центрального } \\
\text { комітету Комуністичної партії Китаю }\end{array}$ & $\begin{array}{l}\text { Навчання літніх людей, соціальна відповідальність, } \\
\text { новаторський дух, практичні здібності, фрізичне та } \\
\text { психічне здоров'я, фрізична фрорма, естетичні та гуманіс- } \\
\text { тичні якості }\end{array}$ \\
\hline 2018 & Національна конференція з питань освіти & $\begin{array}{l}\text { Моральне виховання, інтелектуальне виховання, спорт, } \\
\text { естетичне виховання, трудове навчання }\end{array}$ \\
\hline
\end{tabular}

Джерело: [5; 7; 8; 9] 
система цінностей і переконань, зразків, стандартів та норм поведінки; як засіб самореалізації особистості або групи у соціальному житті. Необхідно розуміти, що духовна культура фрормує особистість, її погляди, світогляд, ціннісні орієнтації, настанови.

В Китаї термін «духовна культура» здебільшого включає в себе художню освіту, естетичне виховання та гуманістичне вдосконалення. Завдяки співпраці відповідної освітньої політики та політики з 1906 по 2018 рік особливу увагу було приділено естетичній освіті, яка зазнала в цей час підйомів і падінь під час всебічного розвитку політики Китаю. Естетична освіта стала більш стійкою та сприяла якісній освіті в Китаї з 1999 року (табл. 1).

Протягом останніх 6 років естетична освіта в Китаї почала «розквітати». На Третьому пленарному засідання XVIII ЦК партії (2013) в ст. 42 згадувалося про «покращення естетичної освіти та вдосконалення естетичних та гуманістичних якос- тей студентів», вказуючи на відсутність, сприяння та впровадження естетичної освіти.

Щодо визначення поняття «естетичного виховання», то багато споріднених словників, а також джерел літератури дають різні його визначення. Наприклад, Tang Jieying (2002) зібрав, упорядкував та проаналізував понад 50 видів концепцій «естетичного виховання», вироблених сучасністю, і поділив їх на вісім категорій: естетичне виховання, яке $€$ допоміжним засобом морального виховання; це освіта естетичних знань; мистецька освіта; емоційне виховання; естетичне виховання; освіта для виховання естетичних здібностей; освіта «всебічної освіти»; сфрера виховання тощо. Ці вісім концепцій 3 різних позицій визначення «естетичного виховання» відображають академічне його розуміння (табл. 2).

Естетична освіта повинна охоплювати навчання в закладах освіти та відігравати важливу роль

Позиції та погляди на розуміння взаємозв'язку понять «духовна культура», «естетичне виховання» та «художня освіта»

\begin{tabular}{|c|c|}
\hline Автор & Позиції та погляди \\
\hline Шиллер (Німеччина) & $\begin{array}{l}\text { Тільки торуючи шлях чесноти, можна досягти свободи та повернути «гармонію» люд- } \\
\text { ської природи. }\end{array}$ \\
\hline Гегель (Німеччина) & $\begin{array}{l}\text { Починаючи від ідеалізму, сприймаючи ідею як першу у світі крізь процес «самозрос- } \\
\text { тання та розвитку» природи, а також мистецтва, фрілософії, релігії, науки, соціальних } \\
\text { систем можна виховати людину. }\end{array}$ \\
\hline Цай Юаньпей (Китай) & $\begin{array}{l}\text { Реалізація «естетичного виховання» у духовному та культурному вихованні сприймає } \\
\text { мистецтво як освіту, культивує знання про створення краси та цінування, яке поширю- } \\
\text { ється на суспільство. }\end{array}$ \\
\hline Цай Юаньпей (Китай) & $\begin{array}{l}\text { Духовні та культурні цінності педагогіки доповнюються естетичним вихованням та інте- } \\
\text { лектуальним вихованням (Словник освіти, } 1930 \text { рік). }\end{array}$ \\
\hline Ван Говей (Китай) & $\begin{array}{l}\text { Дух розділений на три частини: інтелектуальна сила, почуття і воля. Для цих трьох } \\
\text { частин існують ідеали істини, краси та добра; ідеал інтелектуального істинного - це } \\
\text { освіта, а освіта поділяється на три частини: інтелектуальне виховання, моральне вихо- } \\
\text { вання (тобто воля) та естетичне виховання (тобто емоційне виховання). Повна освіта } \\
\text { не обходиться без цих трьох складників (Shu Xincheng, } 1961 \text { рік). }\end{array}$ \\
\hline Лю Shouqi (Китай) & $\begin{array}{l}\text { Естетичне виховання - це освіта дітей і підлітків за допомогою літератури, мистецтва } \\
\text { та використання краси в природі та реального середовища для фрормування правиль- } \\
\text { них естетичних поглядів, розвитку мистецьких талантів, морального виховання (Лю } \\
\text { Шукі, } 1980 \text { рік). }\end{array}$ \\
\hline Цінь Хемін (Китай) & $\begin{array}{l}\text { Духовна та культурологічна просвітницька діяльність спрямована на систематичне } \\
\text { навчання учнів правильним естетичним ракурсам, щоб підвищити інтерес учнів та } \\
\text { вміння виявляти красу, цінувати красу та творити красу (Qin Heming, } 1985 \text { рік). }\end{array}$ \\
\hline Гуан Да (Китай) & $\begin{array}{l}\text { Завдяки літературі, мистецтву та використанню природи, щоб відчути красу реального } \\
\text { життєвого середовища, учнів навчають краси, щоб фрормувати свої правильні естетичні } \\
\text { погляди та вміння цінувати та творити красу (Гуан Да, } 1986 \text { рік). }\end{array}$ \\
\hline Ян Еньхуань (Китай) & $\begin{array}{l}\text { Відповідно до естетично-психологічних характеристик освіти впроваджуйте цілеспря- } \\
\text { моване виховання для виховання емоцій та душі тих, хто отримує освіту (1987 рік). }\end{array}$ \\
\hline $\begin{array}{c}\text { Ю. Бабанський } \\
\text { (Радянський Союз) }\end{array}$ & $\begin{array}{l}\text { Процес спільної діяльності між викладачами та студентами з метою виховання у сту- } \\
\text { дентів естетичних якостей (1987 рік). }\end{array}$ \\
\hline Ян Чанцзян (Китай) & Злиття естетики та педагогіки - це реалізація та застосування естетики в освіті (1988 рік). \\
\hline Пен Руожі (Китай) & $\begin{array}{l}\text { Вихователі спрямовують учнів опанувати основні знання систематичної естетики та } \\
\text { суміжних дисциплін (фрілософрія, педагогіка, література, психологія, фрізіологія тощо), } \\
\text { виховують в учнів здатність відчувати красу, цінувати та виражати красу, спочатку ство- } \\
\text { рювати красу відповідно до правил краси та сприяти фрізичній красі. Комплексний набір } \\
\text { освітніх заходів, що виховують естетичні настрої, мають творчі таланти та встановлю- } \\
\text { ють естетичні ідеали (1988 рік). }\end{array}$ \\
\hline Бамбук Фенікс (Китай) & $\begin{array}{l}\text { Освіта, яка виховує естетичні здібності, естетичні настрої та інтерес до мистецтва, - це } \\
\text { основні завдання (1989 рік). }\end{array}$ \\
\hline
\end{tabular}


Продовження таблиці 2

\begin{tabular}{|c|c|}
\hline Лю Чжаодзі (Китай) & Розвивати вміння учнів до естетичного хобі та створення краси (1990 рік). \\
\hline Чжао Лінглі (Китай) & $\begin{array}{l}\text { Навчальна діяльність, яка розвиває естетичне сприйняття, естетичне осмислення, } \\
\text { естетичну оцінку та естетичну творчість учнів за допомогою різних красивих речей, а } \\
\text { також сприяє вихованню доброї особистості та просвітницької мудрості (1991 рік). }\end{array}$ \\
\hline Ю Чжень (Китай) & $\begin{array}{l}\text { Естетичне виховання та виховання настроїв мають те саме ім'я, що означає прагнення } \\
\text { до всебічного розвитку особистості (1913 рік). }\end{array}$ \\
\hline Zeng Fanren (Китай) & $\begin{array}{l}\text { Естетична освіта спрямована на культивування людей з емоційною здатністю до есте- } \\
\text { тичного судження в об'єктивній реальності через створення образів краси (2002 рік). }\end{array}$ \\
\hline $\begin{array}{l}\text { Чжун Шилунь, } \\
\text { лі Тяньдао (Китай) }\end{array}$ & $\begin{array}{l}\text { Естетична освіта в коледжі стосується використання природної краси, соціальної } \\
\text { краси, художньої краси та інших фрорм емоційного очищення, темпераменту та підви- } \\
\text { щення здатності учнів відчувати красу, цінувати красу, творити красу та культивувати їх } \\
\text { правильні естетичні концепції, естетичні ідеали та естетичні смаки (Освіта, } 2006 \text { рік). }\end{array}$ \\
\hline $\begin{array}{l}\text { Третє пленарне засі- } \\
\text { дання Центрального } \\
\text { комітету 18-го КПК } \\
\end{array}$ & $\begin{array}{l}\text { Удосконалити естетичну освіту та вдосконалити естетичні та гуманістичні якості учнів } \\
\text { [10]. }\end{array}$ \\
\hline $\begin{array}{l}\text { Генеральний офріс Дер- } \\
\text { жавної ради (Китай) }\end{array}$ & $\begin{array}{l}\text { Естетичне виховання - це духовне виховання, яке може не тільки підвищити естетичну } \\
\text { якість людей, але й тонко вплинути на емоції, смаки, темпераменти, розум людей, надих- } \\
\text { нути людський дух і зволожити їхнє серце. Естетичне моральне, інтелектуальне вихо- } \\
\text { вання та спорт доповнюють один одного та сприяють розвитку один одного (2015 рік). }\end{array}$ \\
\hline Цзя Лінінг (Китай) & $\begin{array}{l}\text { Естетична освіта в коледжі визначається як використання природної краси, соціаль- } \\
\text { ної краси, художньої краси та технологічної краси для виховання здатності студентів } \\
\text { відчувати красу, цінувати красу, створювати красу, встановлювати правильну естетику, } \\
\text { виховувати свої настрої та пропагувати свою особистість. }\end{array}$ \\
\hline Міністерство освіти КНР & $\begin{array}{l}\text { Краса - важливе джерело чистоти та моральності. Шкільне естетичне виховання - це } \\
\text { робота, яка спрямована на те, щоб вибудувати душу та вдосконалити естетичні та } \\
\text { гуманістичні якості учнів, залучати учнів до встановлення правильних естетичних кон- } \\
\text { цепцій, виховання благородних моральних почуттів, формування прекрасної душі та } \\
\text { пропагування духу китайської освіти, виховання людей, краси людей, виховання краси } \\
\text { (2019 рік). }\end{array}$ \\
\hline $\begin{array}{l}\text { І.С. Содорова } \\
\text { (Україна) }\end{array}$ & $\begin{array}{l}\text { Національний план «Освіта» («Україна в } 21 \text { столітті»), Національний план «Вчитель», } \\
\text { Доктрина розвитку національної освіти України в } 21 \text { столітті, Закон України «Про вищу } \\
\text { освіту». Модернізація освітнього простору вимагає, щоб фрахівці не лише використо- } \\
\text { вували професійні знання в навчальній діяльності, а й уміло користувалися засобами } \\
\text { естетики та виховного впливу. }\end{array}$ \\
\hline $\begin{array}{l}\text { Віолетта Рапо } \\
\text { (Україна) }\end{array}$ & $\begin{array}{l}\text { Зміст духовних і культурних цінностей, які слід прищеплювати в процесі університет- } \\
\text { ської освіти. }\end{array}$ \\
\hline $\begin{array}{l}\text { Д.В. Мирошиненко } \\
\text { (Україна) }\end{array}$ & $\begin{array}{l}\text { При моделюванні процесу фрормування моральних і духовних якостей учнів основні } \\
\text { методологічні засади та принципи гуманістичного виховання (орієнтоване на людину } \\
\text { навчання, розвиток загальної особистості, індивідуалізація освіти і навчання тощо), } \\
\text { основні позиції гуманістичної моралі та усвідомлення. }\end{array}$ \\
\hline $\begin{array}{l}\text { Ya.M Bugerko } \\
\text { (Україна) }\end{array}$ & $\begin{array}{l}\text { Розвиток духовної культури учнів - це процес поглиблення самопізнання молодих } \\
\text { людей, здатності до підготовки та здатності молоді розуміти і розмірковувати над духо- } \\
\text { вним досвідом, щоб усвідомити потребу ціннісного самовизначення. Духовний досвід } \\
\text { розкривається як частина змісту навчального процесу. }\end{array}$ \\
\hline $\begin{array}{l}\text { О.В. Безсмертна } \\
\text { (Україна-Польща) }\end{array}$ & $\begin{array}{l}\text { Педагогічне дослідження вимагає визначення та практичного застосування методів } \\
\text { культури та аксіології в загальному навчальному процесі студентів коледжу, виховання } \\
\text { в них естетичного досвіду. Виховувати в учнів культуру, самооцінку та унікальну осо- } \\
\text { бистість із гуманістичної точки зору. }\end{array}$ \\
\hline Леві Сміт (США) & Викладайте мистецтво як гуманітарну дисципліну. \\
\hline Брок Парсонс (США) & «Художнє виживання» між естетикою та художньою педагогікою. \\
\hline Едіт Еріксон (США) & $\begin{array}{l}\text { Мистецтво - це діяльність, яка робить історію мистецтва частиною загальної освіти } \\
\text { молоді. }\end{array}$ \\
\hline Артур Еверленд (США) & Художня освіта повинна бути різноманітною, а переслідувана мета - чітко визначеною. \\
\hline Herb Reed [англійська] & $\begin{array}{l}\text { Відповідно до природних тенденцій освічених осіб завдяки належній художній освіті } \\
\text { необхідно виховувати інноваційний дух і розвивати гармонійну особистість. }\end{array}$ \\
\hline $\begin{array}{l}\text { Жан Діас, Марта Баррі } \\
\text { Маккенна (США) }\end{array}$ & $\begin{array}{l}\text { Педагоги використовують навчання як своє мистецтво, створюючи навчальні зустрічі } \\
\text { із пристрастю та почуттями, а також залишаючи учням яскраві враження, зростання } \\
\text { та зміни. }\end{array}$ \\
\hline Smith R.A (США) & $\begin{array}{l}\text { Завдання естетичного виховання полягає в тому, щоб точно розділити рівень раціо- } \\
\text { нальності та ціннісної обґрунтованості, який слід використовувати, коли необхідно } \\
\text { про щось судити (1967 рік). }\end{array}$ \\
\hline
\end{tabular}

Джерело: $[1 ;$ 5; 7; 8; 9; 10; 12; 13; 14; 15] 
у покращенні естетичної та гуманістичної грамотності учнів та студентів. Наприкінці 2015 року Генеральне бюро Державної ради випустило «Думки про всебічне зміцнення та вдосконалення естетичної освіти в школах», де вперше висловило пропозиції щодо побудови системи навчальних програм із естетичної освіти. Того ж року естетичне виховання було включено до Закону «Про освіту» та Закону «Про вищу освіту». Законодавчі гарантії естетичної освіти в школах, особливо в університетах, визначили вимоги щодо її реалізації.

У 2019 році Міністерство освіти випустило висновки щодо ефективного зміцнення роботи 3 естетичної освіти в коледжах та університетах Нової доби та склало нові домовленості, плани естетичного виховання в університетах та в системі естетичної освіти коледжів, які було спрямовано на вдосконалення естетичних та гуманістичних якостей учнів [8]. Отже, країна надає великого значення розвитку та реформуванню естетичного виховання, морального, інтелектуального, фрізичного та мистецького возз'єднання, які фрормують і розвивають елементи та структуру загального розвитку людського тіла та розуму.

Навчальні ресурси, методи викладання в коледжах та університетах забезпечують студентам більше свободи в навчанні, впливають на розвиток духовного та культурного мислення студентів більше, ніж у закладах середньої освіти. Ці відмінності неминуче змусять духовну культуру в коледжах та університетах відрізнятися від рівня освіти в початкових і середніх школах у всіх її аспектах [4].

Художні дисципліни викладачів коледжу здебільшого включають музику, мистецтво, танець та інші спеціальності. Спільністю цих професій $є$ співпереживання та практика. Естетична освіта коледжу керується естетичними теоріями, а основними каналами $€$ не література, а мистецтвознавство.

Завдяки оцінці китайських і зарубіжних літературно-мистецьких вишуканих творів, осягнення прекрасної культурної спадщини людини та діяльності по створенню краси, необхідно виховувати в учнів коледжу правильні естетичні концепції, естетичні смаки, естетичну уяву та естетичні емоції, щоб сорормувати піднесений естетичний стан та естетичний ідеал; розвивати вміння відчувати прекрасні речі та вміння творити відповідно до правил краси, покращувати культурні якості студентів коледжу, робити їх талантами високого рівня з благородною мораллю, знаннями, сильним станом і досконалою особистістю. Отже, духовна культура в коледжах та університетах стосується розуміння естетичної освіти, яка визначає природну красу, соціальну красу та мистецьку красу для фрормування та розвитку духовності студентів, вдосконалення їх здатності відчувати, цінувати і творити красу, а також культивувати її правильні естетичні концепції, естетичні ідеали.
Як свідчить педагогічний досвід, фрормування духовності молоді засобами мистецтва набуває ефективності під час організації й проведення позааудиторної виховної роботи зі студентами, а також під час проведення занять, особливо гуманітарного спрямування.

Доцільно і вміло організована робота духовно-етичного та естетичного спрямування має величезний навчально-виховний потенціал. Вона надає можливості для набуття студентською молоддю досвіду спілкування 3 творами різних видів мистецтв, збагачення естетичних знань і уявлень, формування естетичної свідомості, розвитку особистісних якостей (духовних, комунікативних, пізнавальних, організаторських, креативних), розвиває духовні цінності, сприяє духовній самореалізації, фрормує Людину Культури. Крім того, естетичне та духовно-моральне виховання стимулює творчу самореалізацію майбутніх фрахівців, пов'язану зі створенням і примноженням цінностей мистецтва, створює основу для здійснення професійної діяльності 3 урахуванням вимог естетичної культури суспільства, його духовних ідеалів.

Висновки. Отже, теоретичний аналіз досліджуваної проблеми довів важливість і необхідність фрормування духовних цінностей і духовної культури студентської молоді в університетах Китаю. Ефективність естетичного виховання як однієї зі складових частин духовної культури студентської молоді забезпечується цілеспрямованим підбором оптимальних фрорм, методів, прийомів, засобів педагогічної діяльності викладачів естетичного, духовно-етичного, морально-емоційного спрямування, а також створенням духовного простору у вищій школі, привнесенням енергії краси, добра, істини в атмосферу освітніх закладів, особистісним духовно-моральним авторитетом педагогів, реалізацією духовних цінностей 3 метою формування культури серця особистості на засадах загальнолюдських, національних, всепланетарних цінностей.

Проведене теоретичне дослідження питання фрормування духовних цінностей і духовної культури в університетах Китаю спонукає звернути увагу на управління розвитком духовної культури викладачів університетів та на інновації в управлінні фрормуванням духовної культури в майбутніх вчителів музики.

\section{БІБЛІОГРАФІЧНИЙ СПИСОК:}

1. Авдіянц Г.Г. Духовна культура як основа гуманізації вищої педагогічної освіти // Проблеми гуманізації навчання та виховання у вищому навчальному закладі освіти : Матеріали Четвертих Ірпінських міжнародних науково-педагогічних читань. Ірпінь : Національна академія ДПС України, 2006. 494 с.

2. Алексеев П.В., Панин А.В. Философия. Учебник. М. : Проспект, 1999. 
3. Бичко А.К., Бичко І.В., Табачковський В.Г. Історія фрілософрії. К., 2001.

4. Борова Т.А. Адаптивне управління професійним розвитком науково-педагогічних працівників у контексті європейських цінностей забезпечення якості вищої освіти / Т.А. Борова // Адаптивне управління. 2018. № 4(7). Режим доступу до ресурсу: http://am.eor.by/index.php/gallery/126-vipusk4-7-2018.

5. Ван Говей. Цілі освіти [A]. Зібрання творів Ван Говей. Ван Говей (т. 3) [C]. Яо Йімінг, Ван Ян, редактор. Пекін : Китай Література та історія преси, 1997. 57 c.

6. Енциклопедія освіти / Акад. пед. наук України; головний ред. В.Г. Кремень. К. : Юрінком Інтер, 2008. 1040 c.

7. Зенг Фанрен. Естетичне виховання в напрямі до XXI століття [M]. Xi'an : Shaanxi Normal University Press, 2002. $280 \mathrm{c}$.

8. Міністерство освіти КНР. Думки Міністерства освіти щодо ефективного зміцнення естетичної освіти в коледжах Нового часу: навчальне мистецтво [2019]. № 2 [EB / OL]. (2019-4-2).
Http://www.moe.gov.cn/srcsite/A17/moe 794/moe 624/ 201904/t20190411 377523.html.

9. Cai Yuanpeí. Думки про нову освіту [A]. Дядько Гао Пінг. Вибрані твори навчальних робіт Саi Yuanpei [C]. Пекін : Народна освітня преса, 2017. С. 5.

10. Tang Jieying. Огляд концепції естетичної освіти [J]. Журнал Нормального університету ПівденноЗахідного Китаю (Humanities and Social Sciences Edition), 2002 (02). C. 70.

11. Чжу Фенг. Китайський словник [Z]. Шанхай : Китайський словник Лу Да Да, 1989.

12. Чжун Шилун, Лі Тяньдао. Вступ до естетичного виховання в коледжах та університетах [M]. Пекін : China Social Science Press, 2006. 7 c.

13. Шу Xincheng. Матеріали сучасної китайської освітньої історії (Том 2) [M]. Пекін : Народна освітня преса, 1981. С. 258-259.

14. Ю. Чжень. Естетична освіта [А]. Ю Юзі, Чжан Юань. Вибрані статті 3 естетичного виховання в сучасному Китаї (1840-1949) [C]. Шанхай : Shanghai Education Press, $201 \mathrm{c}$.

15. Ян Чанцзян. Естетичне виховання [М]. Вухань : Вуханський університетський прес, 1988. 